Diabetologia 11, 63-69(1975)

(c) by Springer-Verlag 1975

\title{
Paradoxical Glucagon Response after Stimulation with Glucose and Arginine in Isolated Pancreatic Sand Rat Islets
}

\author{
M. Ziegler, H.-J. Hahn, B. Ziegler, E. Köhler, and H. Fiedler \\ Central Institute for Diabetes "G. Katsch", Karlsburg, German Democratic Republic \\ Received: June 2, 1973, and in revised form: October 22, 1974
}

\begin{abstract}
Summary. Isolated pancreatic islets of normoglycemic sand rats do not respond to $2.5 \mathrm{mM}$ glucose with an enhanced glucagon secretion, which could be observed in normal Wistar rats. Arginine stimulates glucagon release in the presence of $2.5 \mathrm{mM}$ glucose in Wistar rats as well as in sand rats. The secretion pattern is not caused by insulin deficiency since sand rat islets are characterized by an increased insulin secretion rate in vitro. This paradoxical glucagon se-
\end{abstract}

cretion is not caused by a changed glucagon content but might be related to this species which is able to develop a diabetic syndrome spontaneously.

Key words: Pancreatic islets, insulin secretion, insulin content, glucagon secretion, glucagon content, wistar rats, sand rats, glucose, arginine.
In vivo as well as in vitro it is well established that pancreatic glucagon release is normally stimulated by hypoglycemia, amino acids and intestinal hormones. For example, in vivo it has been observed that glucagon secretion is stimulated in different species [16], by hypoglycemia induced by starvation, phlorrizin or insulin suggesting that glucagon plays an important role in mobilizing stored substrates. Glucagon release in response to different amino acids is stimulated only in the state of normoglycemia or hypoglycemia [5, 7--11], whereas the effect of amino acids is abolished by hyperglycemia [2, 12]. In perfused pancreas and duct-ligated pancreas slices it is possible to demonstrate an enhancement of glucagon secretion by low glucose and high amino acids concentration in the incubation medium $[10,13-15]$, whereas with collagenase isolated islets a significant stimulatory action of low glucose levels in contrast to that of high amino acids levels could not be observed uniformly $[16-21]$. Using a careful isolation technique the glucagon and insulin releasing effect of low and high glucose concentrations and of arginine (in the presence of $2.5 \mathrm{mM}$ glucose) on isolated islets of Wistar rats and sand rats was investigated. In addition to this the glucagon recovery rate as well as the insulin/ glucagon ratio was calculated under different experimental situations. The sand rat was selected as a species, which develops spontaneously a diabetic state under special dietetic conditions [22].

\section{Material and Methods} Animals

Sand rats (Psammomys obesus) captured in the United Arab Republic were adapted for 2 weeks on captivity in Cairo. After a further adaptation period of 8 weeks in the animal house of our institute the experiments were carried out within 10 days. The animals were fed with a fresh vegetable diet consisting of green cabbage, chinese cabbage, meal worms and vitamins (about $30 \mathrm{Cal} /$ day, percentage of dry food: $57 \%$ carbohydrate, $32 \%$ protein, $11 \%$ fat). The "clinical" parameters characterizing the investigated animals are summarized in table 2.

Wistar rats, inbred more than 30 generations in our laboratory, were fed with commercial rat pellets chow (VEB Mischfutterwerk Altglienicke, GDR).

\section{Experimental}

The islets of adult animals of both sexes after $12 \mathrm{~h}$ starvation (water ad libitum) were isolated by means of a modified collagenase technique [23]. Immediately after isolation groups of 10 islets were collected for measurement of insulin and glucagon content. 40 islets were preincubated in $12 \mathrm{ml}$ Krebs-Ringer bicarbonate buffer [24], supplemented with $2.5 \mathrm{mM}$ Dglucose and $5 \mathrm{mg} / \mathrm{ml}$ bovine serum albumin equilibrated with $95 \% \mathrm{O}_{2}$ and $5 \% \mathrm{CO}_{2}(\mathrm{pH} 7.4)$ at $37^{\circ} \mathrm{C}$ for $30 \mathrm{~min}$. Then the islets were divided into four equal groups of 10 . Three of the groups were incubated for $120 \mathrm{~min}$ at $37^{\circ} \mathrm{C}$ in the same type of buffer with addition of 2.5 or $16.5 \mathrm{mM}$ glucose or, $10 \mathrm{mM}$ L-arginine in the presence of $2.5 \mathrm{mM}$ glucose. The remaining 10 islets were used for the determination of insulin and glucagon content, after preincubation.

After incubation the islets were separated from buffer under the stereomicroscope. The buffer was 
quickly frozen and stored $\left(-20^{\circ} \mathrm{C}\right)$ until the hormones were measured. For the determination of the islet content of hormones they were transfered after isolation, preincubation or incubation into $1 \mathrm{mM}$ $\mathrm{HCl}$ containing $0.3 \%(\mathrm{w} / \mathrm{v})$ human serum albumin (HSA) and $0.9 \% \mathrm{NaCl}$, quickly frozen to $-80^{\circ} \mathrm{C}$ and freeze dried. The residue was redissolved and diluted in $40 \mathrm{mM}$ phosphate buffer ( $\mathrm{pH} 7.4$ ) containing $0.3 \%$ HSA NaCl, $0.024 \%$ thiomersal, and $80 \mathrm{ATrU} / \mathrm{ml}$ Contrycal $^{R}$ (RIA-buffer). Glucagon and insulin were assayed radioimmunologically.

\section{Analytical}

Blood samples for glucose and insulin were collected from a tail vein or after decapitation. Blood glucose was determined by a modification of the hexokinase method [25], plasma insulin (immunoreactive insulin activity, IRI) was measured by radioimmunoassay (RIA) using a modification of backtitration method [26]. For determination of glucagon (IRG, immunoreactive glucagon activity) a modification of RIA-technique according to Heding [27] was used. To enhance the immunogenicity glucagon was conjugated with water soluble 1-ethyl-3-(3-diethylaminopropyl) carbodiimide hydrochloride [28]. Glucagon antibodies were raised in rabbits by weekly injections of coupled glucagon $(1 \mathrm{mg})$ emulsified in equal volume of Freund's complete adjuvant. Twice crystallized pork glucagon was used as standard and for iodination with 125I using the chloramine-Tmethod [29].

The specific activity of ${ }^{125} \mathrm{I}$-glucagon was enhanced to $110 \mathrm{mCi} / \mathrm{mg}$ by anion exchange chromatography on QAE-Sephadex A-25 according to Jørgensen [30]. Anti-glucagon serum, standard dilution samples and ${ }^{125}$ I-glucagon were stored at $-20^{\circ} \mathrm{C}$ and thawed immediately before use. All reagents were diluted in RIA-buffer. For determination of immunoreactive glucagon $200 \mu \mathrm{l}$ of anti-glucagon serum were added to triplicates of $100 \mu \mathrm{l}$ of standard or unknown sample. After $16 \mathrm{~h}$ of preincubation at $4^{\circ} \mathrm{C}, 100 \mu \mathrm{l}$ of ${ }_{125} \mathrm{I}$-glucagon was added and after a further incubation period at $4^{\circ} \mathrm{C}$ for $4 \mathrm{~h}$, the antibody-bound ${ }^{125} \mathrm{I}-$ glucagon was precipitated with $2.1 \mathrm{ml}$ ethanol $(91 \%$ $\mathrm{v} / \mathrm{v})$. The index of precision was 0.0211 calculated as the ratio between the standard deviation of $\%$ bound ${ }^{125} \mathrm{I}$-glucagon and the slope of the regression line. The sensitivity was $18.53 \pm 4.13 \mathrm{pg} \mathrm{IRG/tube}$.

The lyophilized islets were assayed in several dilutions to check the cross-reactions of used anti-beefpork glucagon serum $R_{16}$ with IRG of Wistar rats and sand rats.

The content of insulin (IRI) was determined in a modification of the backtitration method already described [31], which also gave evidence for the suitability of rat insulin standards in our antibody system.

For testing the protective effect of protease inhibitors on secreted glucagon $[16,17,20,32]$ we incubated standard glucagon in Krebs-Ringer bicarbonate buffer at $37^{\circ} \mathrm{C}$ up to $6 \mathrm{~h}$ with without or addition of Contrycal $(80 \mathrm{ATrU} / \mathrm{ml})$. The calculated glucagon recovery was used to check glucagon degradation.

\section{Statistical Calculations}

The hormone content, as well as the secretion rate were calculated in ng/islet. The influence of the islet size was excluded by selecting islets of similar size for the investigations (between $150-250 \mu \mathrm{m}$ in diameter [33]. The statistical calculations were made from the mean values \pm S.E.M. between test and control incubations carried out in parallel, in a series of 8 experiments on Wistar rats and 9 investigations on sand rats. The glucagon recovery was estimated as the sum of glucagon secretion (after $120 \mathrm{~min}$ ) and hormone content after incubation referred to the tissue glucagon content before incubation (100\%).

\section{Chemicals}

Collagenase $(141 \mathrm{U} / \mathrm{mg}$ ) was obtained from Worthington Biochemical Corporation, Freehold, New Jersey, USA. Glucagon (for clinical use) for immunization, monocomponent pig glucagon (Lot Nr. MC 9969), and proinsulin free rat insulin (Lot Nr. R 170) for iodination and preparation of standard solutions were donated by NOVO A/S, Copenhagen, Denmark. ${ }^{125}$ I was from Isocommerz $\mathrm{GmbH}$, Dresden, GDR. VEB Arzneimittelwerke, Dresden, GDR, supplied Contrycal ${ }^{\circledR}$. Bovine serum albumin was bought from Behring-Werke, Marburg, FRG; human serum albumin from Institut für Impfstoffe, Dessau, GDR. Thiomersal was purchased from Serva-Feinchemikalien, Heidelberg, FRG; QAE Sephadex A-25, from Pharmacia Fine Chemicals, Uppsala, Sweden and 1-ethyl3-(d-diethylaminopropyl) carbodiimide hydrochloride from Schuchardt, München, FRG. D-glucose and Larginine hydrochloride were obtained from Ferak, Berlin-West. All other substances and salts were of analytical grade.

\section{Results \\ RIA of IRG}

In Fig. 1 the standard curve together with the curves for different dilutions of lyophilized islet extracts 
from sand rats and Wistar rats are shown to be linear and parallel to one another. Since the standard curves are independent of dilution, it is possible to use porcine glucagon as standard and therefore all values are expressed as porcine glucagon equivalents. Standard glucagon preparations from Wistar or sand rats were not available.

The linear slope of the standard curve is expressed by the coefficient of regression $(\mathrm{r}=0.9954 \pm 0.0008$, $\mathbf{n}=11)$. The index of precision $(\lambda=0.0412 \pm 0.0064)$ demonstrates the low standard deviation of the assay procedure.

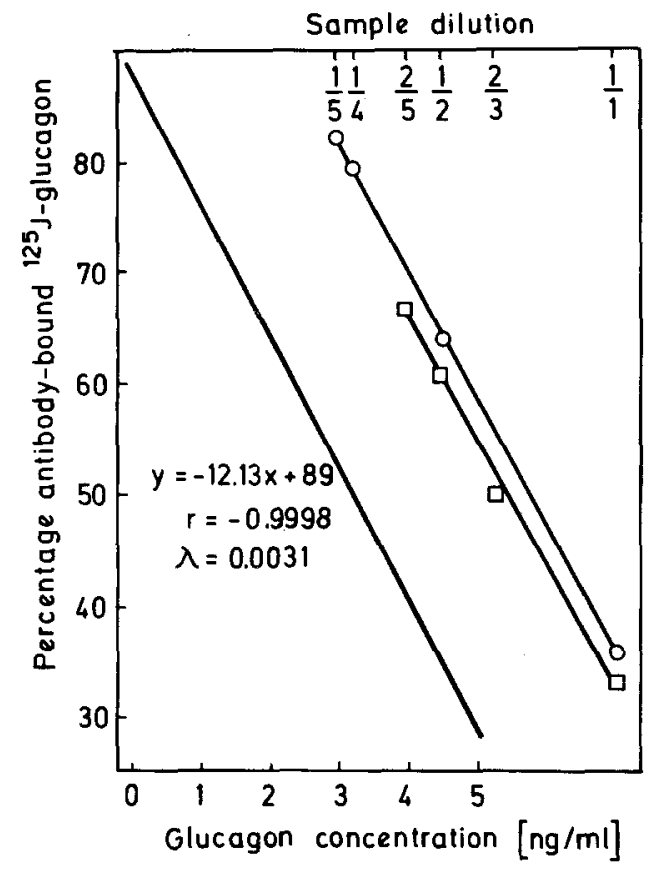

Fig. 1. Comparison of standard curve (-) of pig glucagon and dilution curves of pancreatic glucagon from islets of Wistar rats $(\diamond-\diamond)$ and sand rats $(\bigcirc-O) . \mathrm{r}$ represented the index of correlation, $\lambda$ the index of precision of the standard curve

\section{Glucagon Degradation}

The absence of any fall in IRG concentration in the KRB buffer without or with addition of Contrycal is shown in Table 1. Therefore all incubations for measurement of glucagon secretion could be carried out without added enzyme inhibitors. This conclusion is also supported by the calculated glucagon recovery (see Table 4).

\section{Content and Secretion of Insulin and Glucagon}

Both species used in this study are normoglycemic and without any signs of hyperinsulinism (Table 2). The insulin as well as the glucagon content of isolated islets and the molar insulin/glucagon ratio do not differ between the species (Table 2).

The insulin secretion of isolated pancreatic islets from Wister rats was significantly stimulated by 16.5 $\mathrm{mM}$ glucose or $10 \mathrm{mM}$ arginine in the presence of 2.5 $\mathrm{mM}$ glucose (Table 3 ). The sand rat islets also re-

Table 1. Stability of glucagon in buffer. A Standard solution of glucagon was incubated without or with addition of Contrycal for up to $6 \mathrm{~h}$ in Krebs-Ringer bicarbonate at $37^{\circ} \mathrm{C}$. At the indicated time samples were removed for measuring the glucagon concentration. The results are expressed in $\mathrm{ng} / \mathrm{ml}$ as mean \pm S.E.M. of 6 different experiments

\begin{tabular}{lrrrrr}
\hline & \multicolumn{5}{c}{ Incubation time (h) } \\
\cline { 2 - 6 } medium & \multicolumn{1}{c}{0} & \multicolumn{1}{c}{1} & \multicolumn{1}{c}{2} & \multicolumn{1}{c}{4} & \multicolumn{1}{c}{6} \\
\hline KRB-buffer & 4.51 & 4.78 & 4.63 & 4.39 & 4.61 \\
without contrycal & \pm 0.03 & \pm 0.04 & \pm 0.09 & \pm 0.06 & \pm 0.07 \\
KRB-buffer & & & & & \\
with contrycal & 4.44 & 4.27 & 4.44 & 4.20 & 4.32 \\
(80 ATrU/ml) & \pm 0.01 & \pm 0.13 & \pm 0.18 & \pm 0.08 & \pm 0.06 \\
\hline
\end{tabular}

Table 2. Characterization of investigated animals. Blood samples for determination of blood glucose as well as plasma insulin concentration were collected from the tail vein or after decapitation. The insulin and glucagon content of isolated islets were assayed immediately after isolation as described in "materials and methods". The results are expressed as mean \pm S.E.M. from 8 experiments using Wistar rats and 9 investigations on sand rats, respectively. For calculation of the molar insulin/glucagon ratio the following molecular weights were used: insulin - 5777, glucagon - 3485

\begin{tabular}{lcccc}
\hline & \multicolumn{2}{c}{ Wistar rats } & \multicolumn{2}{c}{ sand rats } \\
\hline Body weight $(\mathrm{g})$ & 174 & \pm 4 & 155 & \pm 9 \\
Blood glucose $(\mathrm{mg} / 100 \mathrm{ml})$ & 68 & \pm 4 & 64 & \pm 6 \\
Plama insulin $(\mu \mathrm{U} / \mathrm{ml})$ & 54 & \pm 4 & 63 & \pm 5 \\
Insulin content $(\mathrm{ng} / \mathrm{islet})$ & 74.5 & \pm 4.5 & $72.1 \pm 2.9$ \\
Glucagon content $(\mathrm{ng} /$ islet $)$ & $3.04 \pm 0.08$ & $2.67 \pm 0.13$ \\
Insulin/glucagon ratio & $19.2 \pm 1.4$ & $17.2 \pm 0.9$ \\
\hline
\end{tabular}

sponded under identical conditions with an increased rate of insulin secretion. But since the hormone output at low glucose was higher, the relative efficiency of the stimulus was not so pronounced. Furthermore the response of the B-cells was not as uniform as that seen in islets of Wistar rats.

Glucagon response of the islets of Wistar rats was characterized by a significant stimulus of IRG secretion by low glucose concentration in the presence or absence of arginine when compared to $16.5 \mathrm{mM}$ glu- 
cose. The effect of $10 \mathrm{mM}$ arginine $+2.5 \mathrm{mM}$ glucose was significantly $(P<0.05)$ higher than $2.5 \mathrm{mM}$ glucose alone.

In contrast to the glucagon response of Wistar rats glucagon release. This ratio was exaggerated in all investigations on sand rat islets in vitro. This was a result of the enormous amont of secreted insulin and absent $\mathrm{A}_{2}$-cell response with $2.5 \mathrm{mM}$ glucose alone,

Table 3. Insulin and glucagon release of isolated pancreatic islets in response to glucose and arginine. Islets were preincubated for $30 \mathrm{~min}$ in Krebs-Ringer bicarbonate buffer with $2.5 \mathrm{mM}$ glucose. 10 islets per vessel were then incubated for $120 \mathrm{~min}$ in $3.0 \mathrm{ml} \mathrm{KRBB}$ medium under the indicated test situations. Mean values \pm S.E.M. are given for each group

\begin{tabular}{|c|c|c|c|c|c|c|}
\hline & \multicolumn{3}{|l|}{ Wistar rat } & \multicolumn{3}{|l|}{ Sand rat } \\
\hline & glucose & & & glucose & & \\
\hline & $2.5 \mathrm{mM}$ & $16.5 \mathrm{mM}$ & $\begin{array}{l}10 \mathrm{mM} \text { arginine } \\
2.5 \mathrm{mM} \text { glucose }\end{array}$ & $2.5 \mathrm{mM}$ & $16.5 \mathrm{mM}$ & $\begin{array}{l}10 \mathrm{mM} \text { arginine } \\
2.5 \mathrm{mM} \text { glucose }\end{array}$ \\
\hline $\begin{array}{l}\text { Insulin release } \\
\text { (ng/islet } / 120 \mathrm{~min} \text { ) }\end{array}$ & $3.11 \pm 0.60$ & $14.55 \pm 1.17$ & $7.11 \pm 1.08$ & $8.50 \pm 1.25$ & $20.80 \pm 2.62$ & $16.40 \pm 2.33$ \\
\hline $\begin{array}{l}P \text { (compared to } \\
2.5 \mathrm{mM} \text { glucose) }\end{array}$ & & $<0.001$ & $<0.001$ & & $<0.005$ & $<0.05$ \\
\hline $\begin{array}{l}\text { Glucagon release } \\
\text { (ng/islet/120 min) }\end{array}$ & $0.39 \pm 0.07$ & $0.22 \pm 0.04$ & $0.58 \pm 0.08$ & $\begin{array}{l}0.09 \pm 0.02 \\
(0.48)\end{array}$ & $\begin{array}{l}0.33 \pm 0.07 \\
(0.70)\end{array}$ & $\begin{array}{l}0.20 \pm 0,05 \\
(0.37)\end{array}$ \\
\hline $\begin{array}{l}P \text { (compared to } \\
2.5 \mathrm{mM} \text { glucose) }\end{array}$ & & $<0.02$ & $<0.05$ & & $<0.01$ & $<0.05$ \\
\hline $\begin{array}{l}\text { Molar insulin/ } \\
\text { glucagon ratio }\end{array}$ & $7.4 \pm 2.1$ & $65.8 \pm 16.1$ & $8.1 \pm 1.1$ & $125.1 \pm 56.9$ & $106.8 \pm 42.8$ & $163.6 \pm 37.3$ \\
\hline $\begin{array}{l}P \text { (compared to } \\
2.5 \mathrm{mM} \text { glucose })\end{array}$ & & $<0.01$ & n.s. & & n.s. & n.s. \\
\hline
\end{tabular}

Table 4. Glucagon recovery from isolated pancreatic islets. The glucagon content of isolated islets was determined immediately after isolation, after $30 \mathrm{~min}$ of preincubation in Krebs-Ringer bicarbonate buffer ( $2.5 \mathrm{mM}$ glucose), corresponding to $100 \%$ for the calculation of the recovery rate, and after $120 \mathrm{~min}$ test incubation under the indicated situations. The revovery (ng/islet) was calculated as the sum of the amounts of IRG in the islets and in the buffer. The statistical significances, judged from the mean values \pm S.E.M. of differences between parallel incubations, are indicated for effects of different stimuli on glucagon content compared to the same parameter after the prestimulatory period $\left({ }^{\mathrm{a}} P<0.05,{ }^{\mathrm{b}} P<0.01\right)$

\begin{tabular}{|c|c|c|c|c|c|c|}
\hline & \multicolumn{3}{|c|}{ Wistar rats $(\mathrm{n}=8)$} & \multicolumn{3}{|c|}{ Sand rats $(\mathrm{n}=9)$} \\
\hline & $\begin{array}{l}\text { Content } \\
\text { (ng/islet) }\end{array}$ & $\begin{array}{l}\text { Secretion } \\
\text { (ng/islet/120 min) }\end{array}$ & $\begin{array}{l}\text { recovery } \\
(\%)\end{array}$ & $\begin{array}{l}\text { Content } \\
\text { (ng/islet) }\end{array}$ & $\begin{array}{l}\text { Secretion } \\
\text { (ng/islet/120 min) }\end{array}$ & $\begin{array}{l}\text { recovery } \\
(\%)\end{array}$ \\
\hline Isolation & $3.04 \pm 0.08$ & & & $2.67 \pm 0.13$ & & \\
\hline Preincubation & $3.03 \pm 0.08$ & & 100 & $2.32 \pm 0.16$ & & 100 \\
\hline \multicolumn{7}{|l|}{ Incubation with } \\
\hline $2.5 \mathrm{mM}$ glucose & $2.70 \pm 0.10^{\mathrm{a}}$ & $0.39 \pm 0.27$ & $102.1 \pm 2.2$ & $2.09 \pm 0.13$ & $0.13 \pm 0.04$ & $95.5 \pm 3.6$ \\
\hline $\begin{array}{l}16.5 \mathrm{mM} \text { glucose } \\
10.0 \mathrm{mM} \text { arginine and }\end{array}$ & $2.90 \pm 0.11$ & $0.22 \pm 0.04$ & $103.2 \pm 5.3$ & $1.84 \pm 0.25$ & $0.36 \pm 0.07$ & $94.6 \pm 4.5$ \\
\hline $2.5 \mathrm{mM}$ glucose & $2.44 \pm 0.12^{b}$ & $0.58 \pm 0.08$ & $99.6 \pm 2.7$ & $2.30 \pm 0.34$ & $0.20 \pm 0.07$ & $107.8 \pm 6.1$ \\
\hline
\end{tabular}

we observed paradoxical glucagon secretion of isolated sand rat islets. With increased glucose concentrations the glucagon secretion was enhanced $(P<0.025)$.

The molar insulin/glucagon ratio of secreted hormones in the Wistar rats was increased under conditions of stimulated insulin secretion and inhibited and also in the presence of $10 \mathrm{mM}$ arginine, to stimulate IRG secretion.

As Table 4 shows, there was no loss of glucagon in our in vitro system. The calculated glucagon recovery (the sum of hormone content of islets and of buffer after incubation) did not differ from the values fol- 
lowing preincubation. The effectiveness of stimulation of Wistar rat islets was supported by decreased glucagon content under conditions of increased IRG release. A similar decrease of glucagon content, could be observed in the sand rat islets after incubation with $16.5 \mathrm{mM}$ glucose.

\section{Discussion}

The sand rat is a desert rodent with an alleged high risk of developing a diabetic syndrome. It was hypothesized that it is possible to alter this metabolic response by controlled nutrition [22]. Because one of the metabolic lesions could be connected with the pancreatic islets [34-36], we investigated the insulin and glucagon secretion as well as the hormone content of pancreatic islets in vitro. We must assume on the basis of the values depicted in Table 2 that the animals principially do not differ significantly from other species with normal metabolism. To exclude methodological influences during the isolation and incubation procedure, the same experimental protocol was used simultaneously on Wistar rats.

During $120 \mathrm{~min}$ incubation the insulin secretion of Wistar rat islets was increased about 5 -fold by 16.5 $\mathrm{mM}$ glucose when compared to $2.5 \mathrm{mM}$ glucose.

Conflicting results concerning the stimulatory action of arginine on insulin secretion in the presence of low glucose concentration have been reported [3742].

Although we did not find a significant increase in insulin secretion in Wistar islets incubated for $30 \mathrm{~min}$ (43), a stimulatory action of arginine was observed after prolonged incubation of $120 \mathrm{~min}$ in the presence of low glucose. Possibly differences in species, incubation time and the experimental situations used, could play an important role in this connection.

Our results and those described earlier [18, 19] demonstrate that collagenase isolated islet of rats are a useful model for investigation of glucagon release. This suggests that the A-cells are not altered significantly by our isolation procedure [44]. As Table 3 shows, $10 \mathrm{mM}$ arginine in presence of $2.5 \mathrm{mM}$ glucose significantly stimulated the glucagon release. It seems important to stress that all incubations were carried out without addition of protease inhibitor. The calculated recovery underlined the suitability of the in vitro conditions used for investigations of insulin and glucagon release. The calculated insulin/glucagon ratio is also in concordance with in vivo results [45] and experiments on perfused pancreas [46].

In contrast to the described glucagon recovery we omitted doing the same of insulin. Two reasons for this may by mentioned, (i) insulin balance during an incubation time of $120 \mathrm{~min}$ is influenced by insulin biosynthesis [47], whereas the rate of glucagon biosynthesis is lower [48], and (ii) Kohnert et al. [49] described an insulin degradating enzyme system, which could be involved in the insulin metabolism of B-cells, influencing the insulin content. Cellular glucagon breakdown cannot be excluded. Using the described in vitro system the results from pancreatic islets of normoglycemic and normoinsulinemic sand rats are in part controversial. As has been established in other species, $16.5 \mathrm{mM}$ glucose stimulated insulin secretion. The relative magnitude of the response compared with $2.5 \mathrm{mM}$ glucose was lower because a large amount of insulin was released in the presence of $2.5 \mathrm{mM}$ glucose. Probably, the glucose threshold was lowered in this species (as preliminary studies have shown [50]). An altered reactivity of sand rat insulin in RIA has been excluded [31]. The calculated recovery from dilution curves rather suggested a diminished binding of sand rat insulin compared with rat insulin.

The sand rat islets did not only fail to exhibit a stimulation of glucagon secretion in response to 2.5 $\mathrm{mM}$ glucose, they responded paradoxically. They showed an increased glucagon secretion at $16.5 \mathrm{mM}$ glucose. At present we cannot decide, whether this fact really represents a stimulation with $16.5 \mathrm{mM}$ glucose or a loss of inhibition.

Unger and coworkers [51] reported a relative hyperglucagonemia in patients with diabetes mellitus. Because such a disorder is also seen in experimental diabetic animals with insulin deficiency $[20,21,45$, 52] it has been hypothesized that the inappopriate stimulation of glucagon secretion is the consequence of the insulin-deficient state. In confirmation of these suggestions an inhibitory effect of insulin on glucagon release was demonstrated $[21,52,53]$, but only with high doses of insulin.

In contrast to the quoted observations, Unger et al. [51] were not able to demonstrate a normalizing effect of insulin administration in adult diabetics with hyperinsulinism. Similar results were reported by Gerich et al. [54] in juvenile diabetics even in the presence of large amounts of exogenously administered insulin. Studies on diabetic animals with hyperglycemia and hyperinsulinemia $[55,56]$ have shown a similar abnormal A-cell response in vitro and the absence of an inhibitory effect of the endogenously secreted insulin. In view of these studies it would be attractive to speculate that the results reported here reflect an early dysfunction of A-cells in connection with the development of diabetes. The paradoxical glucagon secretion seen in the isolated sand rat islets could be observed despite the fact that insulin secretion is rather high while the animals are in a normoglycemic state. 
Although the observations could support the hypothesis of an intrinsic defect of A-cells [54, 57] in normoglycemic sand rats, we cannot exclude that this behavior reflected a species-dependent diminished adaptation on captivity in connection with a response to the "artifically prepared" diet. This disturbance of the insulin/glucagon interaction may be a basis for the development of further alterations in the metabolism of this species.

Acknowledgements. The authors are indebted to NOVO A/S Industri Copenhagen, Denmark for generous gifts of standard rat insulin and pig glucagon. Miss Monika Henkel, Miss Elfi Konradt and Mister Dietmar Klatt were acknowledged for expert technical assistance during these studies.

\section{References}

1. Aguilar-Parada, E., Eisentraut, A. M., Unger, R. H.: Effects of starvation on plasma pancreatic glucagon in normal man. Diabetes 18, 717-723 (1969)

2. Ohneda, A., Aguilar-Parada, E., Eisentraut, A. M., Unger, R. H.: Control of pancreatic glucagon secretion by glucose. Diabetes 18, 1-10 (1969)

3. Buchanan, K. D., Vance, J. E., Dinstl, K., Williams, R. H.: Effect of blood glucose on glucagon secretion in anesthetized dogs. Diabetes 18, 11-18 (1969)

4. Persson, I., Gyntelberg, F., Heding, L. G., Boss-Nielsen, J.: Pancreatic glucagon-like immunoreactivity after intravenous insulin in normals and chronic-pancreatitis patient. Acta endocr. (Kbh.) 67, 401-404 (1971)

5. Ohneda, A., Sato, M., Natsuda, K., Yanbe, A., Maruhama, Y., Yamagata, S.: Plasma glucagon response to blood glucose fall, gastrointestinal hormones and arginine in man. Tohoku J. exp. Med. 107, 241-251 (1972)

6. Gerich, J. E., Schneider, V., Dippe, S. E., Langlois, M., Noacco, C., Karam, J. H., Forsham, P. H.: Characterization of the glucagon response to hypoglycemia in man. J. clin. Endoc. 38, 77-82 (1974)

7. Rocha, D., Faloona, G. R., Unger, R. H.: Glucagon-stimulating activity of 20 amino acids in dogs. J. clin. Invest. $\mathbf{5 1}, 2346-2351$ (1972)

8. Assan, R., Rosselin, G., Dolais, J.: Effects sur la glucagonémie des perfusions et ingestions d'acides animés. I. Ann. Diabétol. de Hôtel-Dieu. 7, 25-41 (1967)

9. Fajans, S. S, Floyd, J. C., jr., Knopf, R. F., Conn. J. W.: Effect of amino acids and proteins on insulin secretion in man. Recent Progr. Hormone Res. 23, 617-662 (1967)

10. Iversen, J.: Secretion of glucagon from the isolated, perfused canine pancrease. J. clin. Invest. 50, 2123-2136 (1971)

11. Kaneto, A., Kosaka, K.: Stimulation of glucagon secretion by arginine and histidine infused intrapancreatically. Endocrinology 88, 1239-1245 (1971)

12. Ohneda, A., Parada, E., Eisentraut, A. M., Unger, R. H.: Characterization of response of circulating glucagon to intraduodenal and intravenous administration of amino acids. J. clin. Invest. 47, 2305-2322 (1968)

13. Leclercq-Meyer, V., Brisson, G. R., Malaisse, W. J.: Effect of adrenaline and glucose on release of glucagon and insulin in vitro. Nature, New Biology 231, 248-249 (1971)

14. Laube, H., Fußgänger, R. D., Schröder, K. E., Pfeiffer, E. F.: Acute effects of human chorionic somatomammo- tropin on insulin and glucagon release in the isolated perfused pancreas. Diabetes 21, 1072-1076 (1972)

15. Assan, R., Boilot, J., Attali, J. R., Soufflet, E., Ballerio, G.: Diphasic glucagon release induced by arginine in the perfused rat pancreas. Nature, New Biology 239, 125126 (1972)

16. Vance, J. E., Buchanan, K. D., Challoner, D. R., Williams, R. H.: The effect of glucose concentration on insulin and glucagon release from isolated islets of Langerhans of the rat. Diabetes 17, 187-193 (1968)

17. Edwards, J. C., Howell, S. L., Taylor, K. W.: Radioimmunoassay of glucagon released from isolated guinea-pig islets of Langerhans incubated in vitro. Biochim. Biophys. Acta (Amst.) 215, 297-309 (1970)

18. Chesney, T. McC., Schofield, J. G.: Studies on the secretion of pancreatic glucagon. Diabetes 18, 627-632 (1969)

19. Nonaka, K., Grillo, T. A. I., Foa, P. P.: Glucagon secretion in normal rats and hamsters and in hamsters with a transplantable islets cell tumor. Wenner-Gren Center Symposium 16, 149-165 (1970)

20. Buchanan, K. D., Mawhinney, W. A. A.: Glucagon release from isolated pancreas in streptozotocin-treated rats. Diabetes 22, 797-800 (1973)

21. Buchanan, K. D., Mawhinney, W. A. A.: Insulin control of glucagon release from insulin-deficient rat islets. Diabetes 22, 801-803 (1973)

22. Hahn, H. J., Wappler, E., Fiedler, H.: Die Sandratte (Psammomys obesus): Ein an Spontandiabetes erkrankendes Tier. Z. Versuchstierk. 13, 275-282 (1971)

23. Hahn, H.-J., Lippmann, H. G., Knospe, S., Michael, R.: Verhalten der Langerhans'schen Inseln des Pankreas in vitro. Acta biol. med. germ. 25, 573-581 (1970)

24. Umbreit, W. W., Burris, R. H., Stauffer, J. F.: Manometric Techniques, 4th. Burgess Publishity Co., Minneapolis 1964, S. 132

25. Stork, H., Schmidt, F. H.: Mitteilung über eine enzymatische Schnellmethode zur Bestimmung des Blutzuckers in 5 ul Kapillarblut ohne Enteiweißung und ohne Zentrifugation. Klin. Wschr. 46, 789-790 (1968)

26. Gottschling, D., Ziegler, M., Wilke, W., Michael, R.: Radioimmunoassay von Plasmainsulin - methodenkritische Untersuchungen. Radiobiol. Radiother. (Berl.) 15, 96-97 (1974)

27. Heding, L. G.: Radioimmunological determination of pancreatic and gut glucagon in plasma. Diabetologia 7 , $10-19$ (1971)

28. Heding, L. G.: The production of glucagon antibodies in rabbits. Horm. Metab. Res, 1, 87-88 (1969).

29. Hunter, W. M., Greenwood, F. C.: Preparation of iodine131 labelled human growth hormone of high specific activity. Nature 194, 495-496 (1962)

30. Jørgensen, K. H., Larsen, U. D.: Purification of 125-I-glucagon by anion exchange chromatography. Horm. Metab. Res. 4, 223-224 (1972)

31. Speck, G. A., Ziegler, B., Hahn, H. J., Ziegler, M.: Radioimmunoassay der immunreaktiven Insulinaktivitäten Langerhans'scher Inseln. Radiobiol. Radiother. (Berl.) 15, 85-89 (1974)

32. Assan, R., Tchobrontsky, G., Derot, M.: Glucagon radioimmunoassay: Technicals problems and recent data. Horm. Metab. Res. Suppl. Series 3, 82-90 (1971)

33. Hahn, H. J., Michael, R., Kansy, H.: Untersuchungen an Langerhans'schen Inseln in vitro. VI. Der Einfluß der Inselgröße auf die Insulinsekretion. Acta biol. med. germ. 25, 939-943 (1970)

34. Malaisse, W. J., Like, A. A., Malaisse-Lagae, F., Gleason, 
R. E., Soeldner, J. S.: Insulin secretion in vitro by the pancreas of the sand rat (Psammomys obesus). Diabetes 17, 752-759 (1968)

35. Hackel, D. B., Frohman, L., Mikat, E., Lebovitz, H. S., Schmidt-Nielsen, K., Kinney, T. D.: Effects of diet on the glucose tolerance and plasma insulin levels of the sand rat (Psammomys obesus). Diabetes 15, 105-114 (1966)

36. Brodoff, B. N., Penhos, J. C., Levine, R.: The effects of feeding and various hormones on the glucose tolerance of the sand rat (Psammomys obesus). Diabetologia 3, 167170 (1967)

37. Lernmark, A.: Effects of neutral and dibasic amino acids on the in vitro release of insulin. Hormones 3, 22-30 (1972)

38. Milner, R. D. G.: The mechanism by which leucine and arginine stimulate insulin release in vitro. Biochim. biophys. Acta (Amst.) 192, 154-156 (1969)

39. Edgar, P., Rabinowitz, D., Merimee, T. J., Almogela, E.: Effect of arginine on insulin release in vitro. Metabolism 18, 84-86 (1969)

40. Malaisse, W, J., Malaisse-Lagae, F.: Stimulation of insulin secretion by non carbohydrates metabolites. J. Lab. clin. Med. 72, 438-448 (1968)

41. Levin, S. R., Grodsky, G. M., Hagura, R., Smith, D. F., Forsham, P. H.: Relationships between arginine and glucose in the induction of insulin secretion from the isolated perfused rat pancreas. Endocrinology 90, 624-631 (1972)

42. Lambert, A. E., Jeanrenaud, B., Junod, A., Renold, A. E.: Organ culture of fetal rat pancreas. II. Insulin release induced by amino and organic acids, by hormonal peptides, by cationic alterations of the medium and by other agents. Biochim. biophys. Acta (Amst.) 184, 540-553 1969)

43. Hahn, H. J., Ziegler, B., Butter, R., Ziegler, M., Henkel, M., Fiedler, H.: Untersuchungen an Langerhans'schen Inseln in vitro. VII. Vergleichende Untersuchungen zur Stimulation der Insulinsekretion durch unterschiedliche Substrate bei der Ratte. Endokrinologie 61, 258-264 (1973)

44. Petkov, P., Hahn, H. J., Galabova, R., Ziegler, M.: Untersuchungen an Langerhans'schen Inseln in vitro. VIJI. Acta histochemica 51, 50-60 (1974)

45. Unger, R. H., Lefebvre, P.: Glucagon Physiology, in Glucagon pp. 213-244 (ed. P. J. Lefebvre and R. H. Unger). Oxford and New York: Pergamon Press 1972

46. Fußgänger, R. D., Grajeda, E., Laube, H., Pfeiffer, E. F.: Insulin- und Glukagonsekretion des isoliert perfundierten Pankreas der Ratte nach verschiedenen Aminosäuren. Vortrag 7. Kongreß Dtsch. Diabetesgesellschaft 4.-6.5. 1972
47. Steiner, D. F., Clark, J. L., Nolan, C., Rubenstein, A. H., Margoliash, E., Aten, B., Oyer, P. E.: Proinsulin and the biosynthesis of insulin. Recent Progr. Hormone Res. 25, $207-282(1969)$

48. Hellerström, C., Howell, S. L., Edwards, J. C., Andersson, A.: An investigation of glucagon biosynthesis in isolated pancreatic islets of guinea pigs. FEBS Letters 27, 97-101 (1972)

49. Kohnert, K. D., Hahn, H. J., Zühlke, H., Schmidt, S., Fiedler, H.: Breakdown of exogeneous insulin by Langerhans islets of the pancreas in vitro. Biochim. biophys. Acta (Amst.) 338, 68-77 (1974)

50. Ziegler, B., Knospe, S., Ziegler, M., Hahn, H. J.: Insulinsekretion kultivierter Langerhans'scher Inseln der Sandratte. Vortrag VIII. Karlsburger Symposion 4.-8.6.1974

51. Unger, R. H., Aguilar-Parada, E., Müller, W. A., Eisentraut, A. M.: Studies of pancreatic alpha cell function in normal and diabetic subjects. J. clin. Invest. 49, 837$848(1970)$

52. Müiler, W. A., Faloona, G. R., Unger, R. H.: The effect of experimental insulin defiency on glucagon secretion. $\mathbf{J}$. clin. Invest. 50, 1992-1999 (1971)

53. Fußgänger, R. D., Goberna, R., Schröder, K. E., Laube, H., Pfeiffer, E. F.: Abnormally high glucagon secretion of the streptozotozin diabetic isolated perfused rat pancreas. Evidence for a lack of suppression due to the deprivation of endogeneous insulin release. Diabetologia 7, (Abstr.) $480(1971)$

54. Gerich, J. E., Langlois, M., Noacco, L., Karam, J. H., Forsham, P. H.: Lack of glucagon response to hyperglycemia in diabetes: Evidence for an intrinsic pancreatic alpha-cell defect. Science 182, 171- 173 (1973)

55. Fußgänger, R., Schwaier, A., Hager, G., Süßmann, H., Pfeiffer, E. F.: Untersuchungen zur Insulin- und Glukagonsekretion am isolierten perfundierten Pankreas von tupaia belangeri. 8. Kongreß Deutsche Diabetesgesellschaft, 21.-23. 6. 1973, München

56. Laube, H., Fußgänger, R. D., Maier V., Pfeiffer, E. F.: Hyperglucagonemia of the isolated perfused pancreas of diabetic mice (db/db). Diabetelogia 9, 400-402 (1973)

57. Buchanan, K. D., McCaroll, A. M.: Abnormalities of glucagon metabolism in untreated diabetes mellitus. Lancet 1972 II, $1394-1395$
Dr. H.-J. Hahn
Dept. of Experimental
Diabetes Research
Central Institute for Diabetes
DDR-2201 Karlsburg
German Democratic Republic 